\title{
各種ゴムとポリエチレンとのブレンド
}

（昭和40年 2 月26日 受理）

\begin{tabular}{|c|c|c|c|c|c|c|c|}
\hline \# & 本 & & 稔*1 & 箕 & 浦 & 有 & 二 $^{* 1}$ \\
\hline & 藤 & 邦 & 夫 $^{* 2}$ & 矢 & 部 & & 暉 $^{* 3}$ \\
\hline & 宮 & & 優*4 & 安 & 藤 & & 勇*5 \\
\hline & 熊 & 勇 & 平 ${ }^{* 6}$ & 剣 & 茎 & & 浩*7 \\
\hline & 田 & 司 & 郎 ${ }^{* 3}$ & 日 & 高 & & 隆*3 \\
\hline & 室 & 経 & 治*10 & 田 & 原 & & 熙*11 \\
\hline & 藤 & & 禗*12 & 妻 & 鹿 & 菊 & $夫^{* 13}$ \\
\hline
\end{tabular}

要 旨 各䅖ゴム (SBR, BR, IR, IIR) と重合法（筒压法，中圧法，低圧法）のことなるポリエチレンを 锃々の割合でロールブレンドし，イオウ加硫して得た加硫物の諸性質を検討した.

その結果，ポリエチレンは各種ゴムに詨しすぐれた低比重補強材となりうることを知った. その補強効果

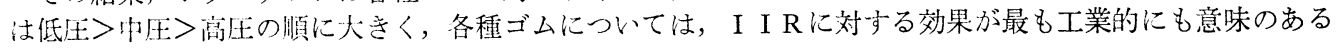
ものであることを知った.

\section{1. 緒言}

ゴムにポリエチレン（以下PEとする）をブレンドす ることは，PEがゴムに対する低比重フィラーだけでな く可塑凨, 加工助戍としての効果も期待することができ よう.

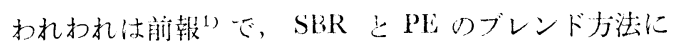
ついて検封し，2〜3の知見至得た.

ここでは，SBR，ブタジェンゴム，ボリイソプレンジ ム，ブチルゴム（以下それぞれ BR，IR，IIR とする） 上，重合法のことなる P E を種々の割合でブレンドし， 主として物理的な面での改質効果を検討した.

その結果，ほとんどすべてのゴムについて P E はすぐ れた低比重補強材となりうることを知った. そして, そ の補強効果は P E 量が増すにしたがい，ほとんど直線的 に増大する傾向があり，ブレンド物の性質は，ゴム単独 の性質およびP E 単独の性質との間に加成性があること を認めた。

\section{SBR とポリエチレンのブレンド}

SBRと高圧法, 中圧法, 低圧法ポリエチレン（以下そ

†本報を〔ゴムと熱可塑性樹脂のブレンドに関する研 究 (第11報) ]とする.

$* 1$ 大阪市立大学工学部 $* 2$ 大阪工業大学 $* 3$ 福助(株)

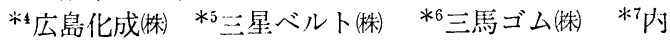
外ゴム侏) ${ }^{* 8}$ 日本合成ゴム侏関西加工技術研究所

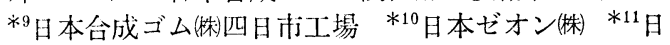
本バルカー(粕 *12坂井化学工業(梸)*13-太陽ゴム工業所
れぞれ PE-H, PE-M, PE-L とする) をロールブレンド して得た，SBR/PE ブレンド比 100/0，75/25，50/50， 25/75，0/100のブレンド物をイオウ一促進剤系で加硫し て諸性質を調べた。

\section{1 実験方法}

2.1.1 試料 実験に供したポリマーを表 1 に示す. 各種PEの主な性質は表 2 に示すとおりである. 配合薬 品は市販品をそのまま用いた.

2.1.2 配合および加硫 配合を表 3 に示す. 加硫は $150^{\circ} \mathrm{C}$ でプレス加硫した. 加硫物は, 加硫操作終了後, プレスしたままモールドに泠水をとおして冷却し，モー

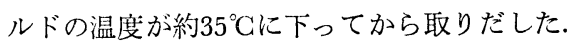

2.1.3 混練 混練は $6^{\prime \prime} \times 26^{3} / 8^{\prime \prime}$ 高圧蒸気加熱式テスト ロール（前ロール回転速度 $15.4 \mathrm{rpm}$ 回転比 $1: 1.22$ ) でおこなった，その手順はつぎのとおりである.

1）ロール蒸気圧 $5 \mathrm{~kg} / \mathrm{cm}^{2}$ で SBR をまきつける. これに $\mathrm{PE}$ を徐々に加え, 見掛け上均一なブレン ド物が得られた後, 10回うす通しする.

2）ロール蒸気圧を $3 \mathrm{~kg} / \mathrm{cm}^{2}$ に下げ, 配合薬品を加え て混練し，10回うす通しする.

3）グリンストックを一夜室温放置したのち，ロール 蒸気圧 $5 \mathrm{~kg} / \mathrm{cm}^{2}$ で所定の厚さにシーティングする.

2.1 .4 諸性質の試験法 加硫物の引張強さ, モジュ ラス, かたさ, 永久伸び, 引裂強さ, 耐油性, 耐摩耗 性を測定した.

試験法は JIS K 6301 に準じた. 詳細はつぎのとおり である. 
表 1 供試ポリマー

\begin{tabular}{|c|c|c|c|}
\hline ポリマー & \multicolumn{2}{|c|}{ 柄 } & 略 号 \\
\hline SBR & \multicolumn{2}{|l|}{ JSR 1502} & SBR \\
\hline 高圧法ポリエチレン & \multicolumn{2}{|c|}{ スミカセン G202 } & PE-H \\
\hline 中圧法ポリエチレン & \multicolumn{2}{|c|}{ ショーレックス 5003A } & PE-M \\
\hline 低圧法ポリエチレン & \multicolumn{2}{|c|}{ ハイゼックス 300B } & PE-L \\
\hline \multicolumn{4}{|c|}{ 表 2 供試ポリエチレンの性質 } \\
\hline 性 & $\begin{array}{c}\text { PE-H } \\
\text { スミカセン G } 202\end{array}$ & $\begin{array}{c}\text { PE-M } \\
\text { ショーレックス } 5003 \mathrm{M}\end{array}$ & $\begin{array}{c}\text { PE-L } \\
\text { ハイゼックス } 300013\end{array}$ \\
\hline 比重 & 0.921 & 0.945 & 0.955 \\
\hline メルトインデックス & 1.6 & 0.3 & 0.8 \\
\hline 降 伏 值 $\left(\mathrm{kg} / \mathrm{cm}^{2}\right)$ & 90 & -.. & 250 以上 \\
\hline 引 張 強 さ $\left(\mathrm{kg} / \mathrm{cm}^{2}\right)$ & 190 & 250 & 250 以上 \\
\hline か た さ(ショアーD) & 45 & 65 & $66 \sim 67$ \\
\hline 敷 化 点 & 91 & 121 & $115 \sim 117$ \\
\hline 融 点 & $107 \sim 113$ & - & $130 \sim 132$ \\
\hline
\end{tabular}

表 3 配合

\begin{tabular}{lc}
\hline 配 合 量 & 重量部 \\
\hline ポリマー & 100 \\
亜鉛華 $(1$ 号 $)$ & 3.0 \\
老化防止剂D & 1.0 \\
ステアリン酸 & 1.0 \\
イオウ & 1.75 \\
促進剤 $\mathrm{CZ}$ & 1.5 \\
\hline
\end{tabular}

引張試験：JIS 1 号ダンベル 型試験片，引張速度 350 $\mathrm{mm} / \mathrm{min}$.

引裂試験：JIS B 型試験片.

摩耗試験：アクロン式摩耗試験機, 取付角 $15^{\circ}$ 荷重 1.81 $\mathrm{kg}$, 予備摩耗1000回, 1000 回摩耗後の容積減 を测定.

耐油試験：ASTM 3 号油に $70^{\circ} \mathrm{C}$ で浸漬, 平衡膨潤に達 したときの体積増加率を測定.

永久伸び試験：JIS 法および等伸長法(100\%伸ビ）を併 用.

\section{2 実験結果および考察}

混練操作は PE-H が最もよく, PE-M, PE-L の順に 低下し，混練操作しやすい試料ほど低温での混練が容易 であった. 加硫物の外観, 手ざわりなどは SBR/PE 比 75/25ではゴム状であるが，50/50ではゴムとプラスチッ クの中䦎的な状態で，25/75 ではほとんどプラスチック に近い状態であった，PE 量の多いブレンド物は，PE の種類にかかわらず伸長時にネッキングが認められ，ま た著しいイオウのブルーミングがみ上められた.

諸性質を図 1 〜 8 に示す.これらの結果からつぎのよ

うに考えられる。

1） PE は SBR の引張強さ，かたさ，引裂強さ，摩 耗抵抗，耐油性を向上させる。しかし，反ぱつ弾性 が低下し，永久伸びが大きくなる.

これらの効果は PE-H より PE-M， PE-L の方が 程度が大きく，L>M>H の順である.

2） PEの種類によらずブレンド物の諸性質はSBR 単 独および PE 単独の諸性質との間にほぼ直線的な関 係があり，ブレンド比 50/50 近辺に変曲点がみとめ られる。これは前報2でものべたよらにゴムとブラ スチックスのブレンド系に执いては，ブレンド比 50/50近辺をさかいとして rubber in plastics およで plastics in rubber に変化するものと考えられる.

3） PE 量の多いブレンド物はネッキングし，著しく イオウがブルーミングする.これはイオウ一促進剤 系による加硫では PE が橋かけされないことを示す ものであろう。

4）永久伸びはJIS 法と $100 \%$ 等伸長法とでまったく ことなった傾向を示している. PE 量の多い試料は ネッキングを生じるまでの伸びが極めて小さいた め，JIS 法では测定時の伸びに著しい差があること に起因すると思われる.ゴム状物からプラスチック 状物までを含む本実験のような場合は，等伸舆法の 方が寒情に即していると思われる.

5）イオウ一促焦剤系ではPE の橋かけがおこなわれ ないため，加硫工程に PE がマイグレイトすること がある。

引張強さーブレンド比の曲線が PE 量の多い部分 


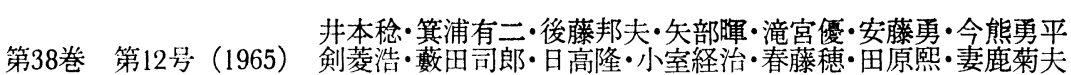

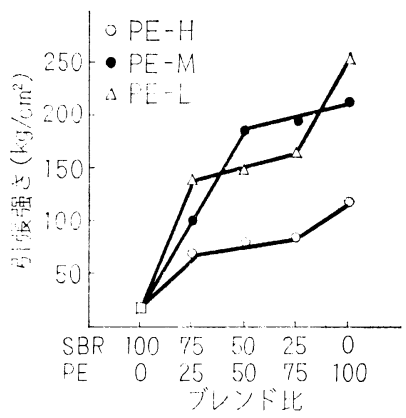

図 $1 \mathrm{SBR} / \mathrm{PE}$ ブレンド物の引張強 $さ$

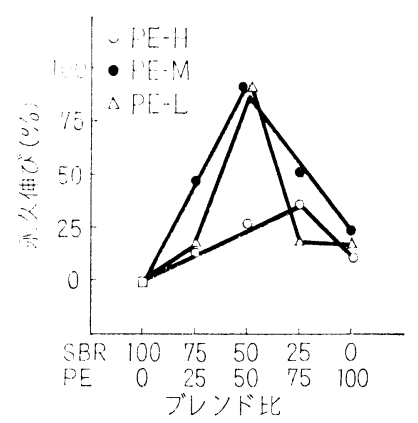

図 $4 \mathrm{SBR} / \mathrm{PE}$ ブレンド物の永久伸 び ( JIS 法)

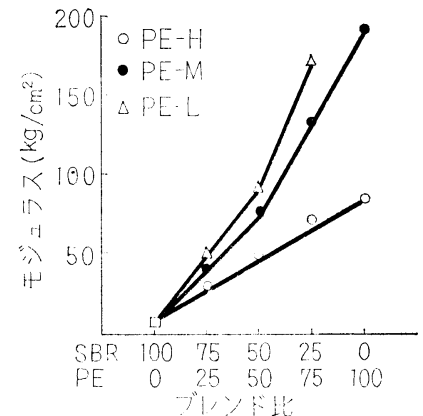

図 $2 \mathrm{SBR} / \mathrm{PE}$ ブレンド物のモジュ ラス $(100 \%)$

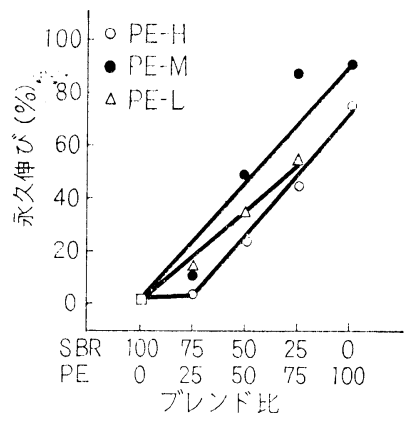

図 $5 \mathrm{SBR} / \mathrm{PE}$ ブレンド物の永久伸 び (等伸長法一100\%)

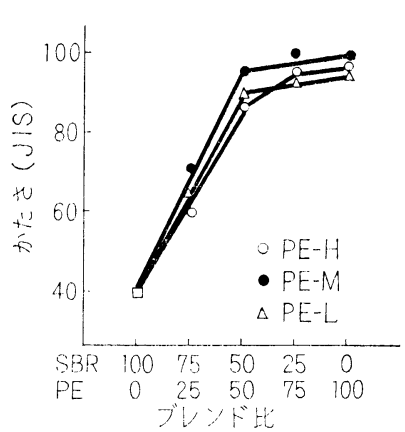

図 3 SBR/PE ブレンド物のかたさ

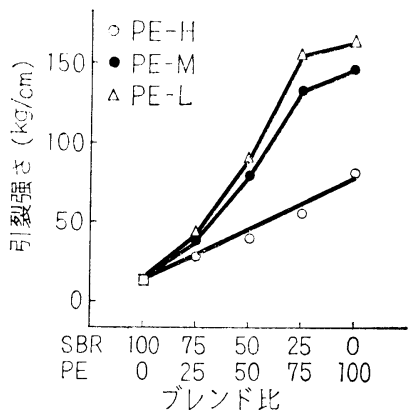

図 $6 \mathrm{SBR} / \mathrm{PE}$ ブレンド物の引裂強 さ

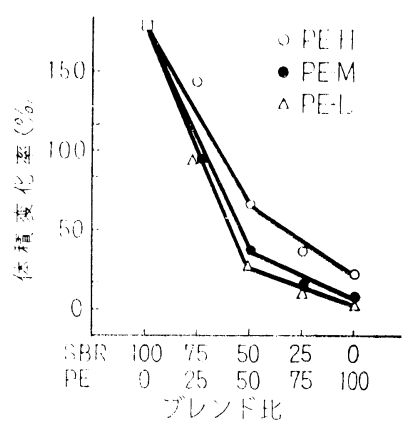

図 $7 \mathrm{SBR} / \mathrm{PE}$ ブレンド物の耐油性

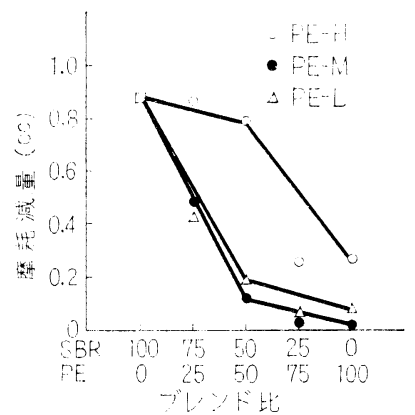

困 $8 \mathrm{SBR} / \mathrm{PE}$ ブレンド物の摩耗性
で緩傾斜になったり，耐油性一ブレンド比曲線が極 小点を示したりするのは, このためと思われる.

以上のことから，PE はSBR の低比重補強材と いえる.

3. ブタジェンゴムとポリエチレンのブレンド

2 種の $\mathrm{BR}$ と $\mathrm{PE}$ をロールブレンドして得た $\mathrm{BR} / \mathrm{PE}$ ブレンド比100/0，80/20，65/35, 50/50,35/65,20/80, $0 / 100$ のブレンド物をイオウ一促進剂系で加硫して諸性
質を調べた。

\section{1 実験方法}

3.1.1 試料および配合 実験に供した BR を表 4 に 示す. PE および配合は前節と同じである（表 $1 ， 2$ お 表 4 供試ポリブタジエンゴム 
よび 3 ).

3.1 .2 混練および加硫 混練は $8^{\prime \prime} \times 24^{\prime \prime}$ 宮压蒸気加 熱式テストロール（前ロール回転速度 $18 \mathrm{rpm}$, 回転比 1 ：1.11）を用いた. 混練手順は前述（2.1.3）にほぼ準 じた．ただし，ブレンドはロール温度 $120 \sim 130^{\circ} \mathrm{G}$ でお こない，配合薬品の添加は BR 量が 65/35より多い試料 はロール温度 $40 \sim 50^{\circ} \mathrm{C} ， 50 / 50$ より $\mathrm{PE}$ 量が多い試料は $120 \sim 130^{\circ} \mathrm{C}$ でおなった.

加硫は $150^{\circ} \mathrm{C}$ でプレス加硫した.

3.1 .3 諸性質の試験法 加硫物の引張強さ, モジュ ラス，伸び，かたさ，永久伸び，引裂強さ，耐油性，耐 摩耗性, 反ぱつ弾性を測定した。試験法は JIS K 6301 に準じた。詳細はつぎのと抢りである.

引張試験：JIS 3 号ダンベル 型試験片, 引張速度 516

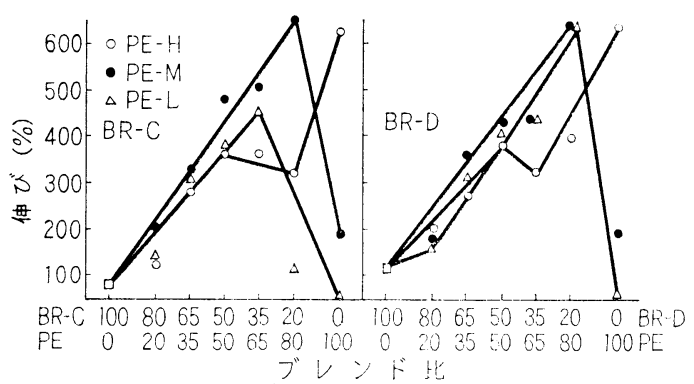

図 $9 \mathrm{BR} / \mathrm{PE}$ ブレンド物の伸び

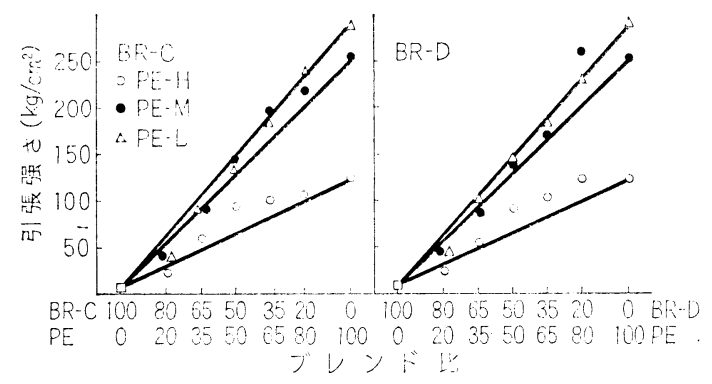

図10 BR/PE ブレンド物の引張強さ

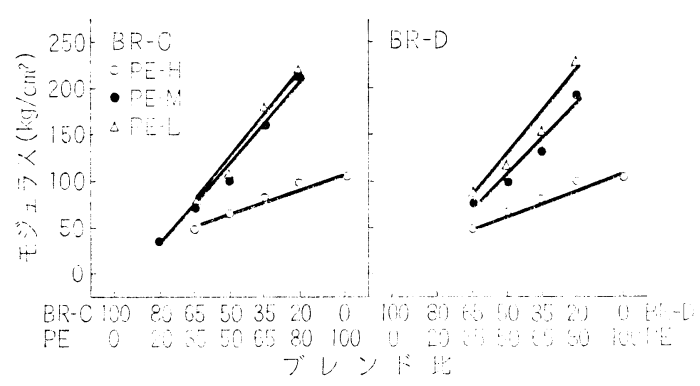

図11 BR/PE ブレンド物のモジュラス（100\%) $\mathrm{mm} / \mathrm{min}$.

耐油試験: ASTM 3 号油に $70^{\circ} \mathrm{C} 70$ 時間浸漬後の体積增 加率を測定.

\section{2 実験結果および考察}

BR 単独試料はロールにまきつき難く, 混練操作が困 難であるが， PE を加えると混練しやすくなり，むしろ SBRとのブレンドより加工性がよくなった. また伸長時 のネッキングも，SBRブレンドほど著しくなかった.

BR-C/PE および BR-D/PE ブレンド物の加硫物の諸 性質を図 9 〜 17に示ず.これらの結果をまとめるとつぎ の上抢りである.

1） PE は BR の引張強さ，引裂強さ，かたさ，摩耗 抵抗，耐油性を向上させる.しかし，反ぱつ弾性， 永久伸びは低下する.

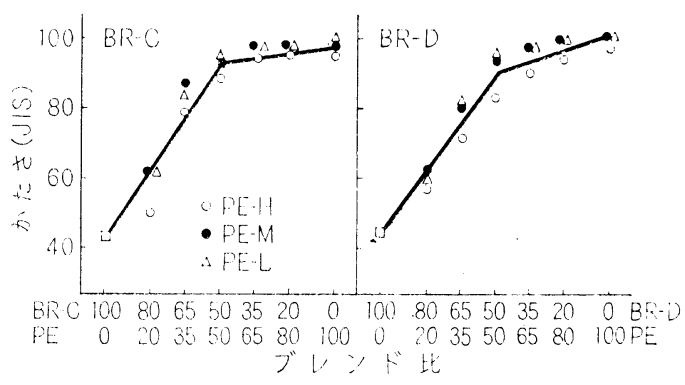

図12 BR/PE ブレンド物のかたさ

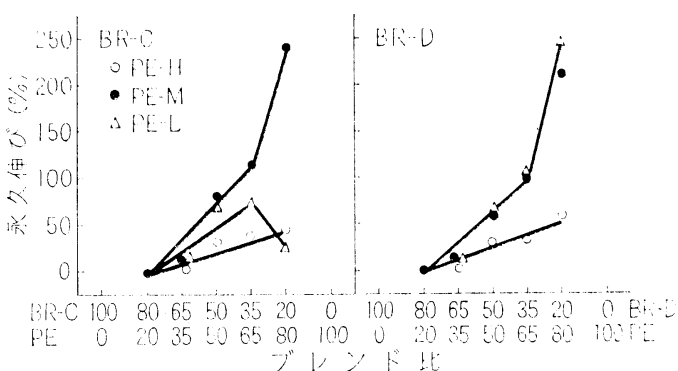

図13 BR/PE ブレンド物の永久伸び

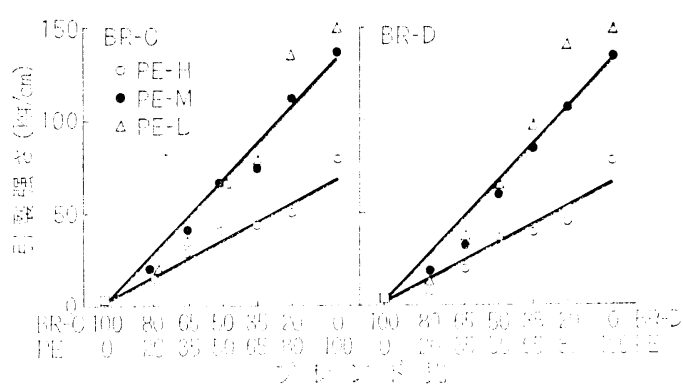

図14. BR/PE ブレンド物の引裂強さ 


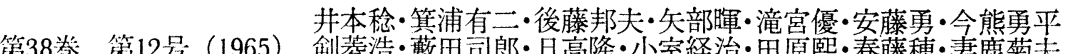

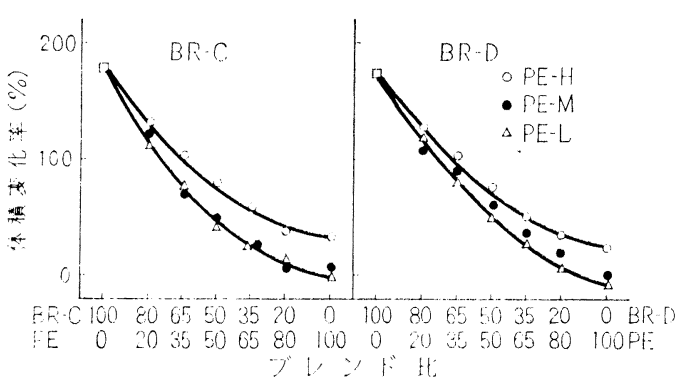

図15 BR/PE ブレンド物の耐油性

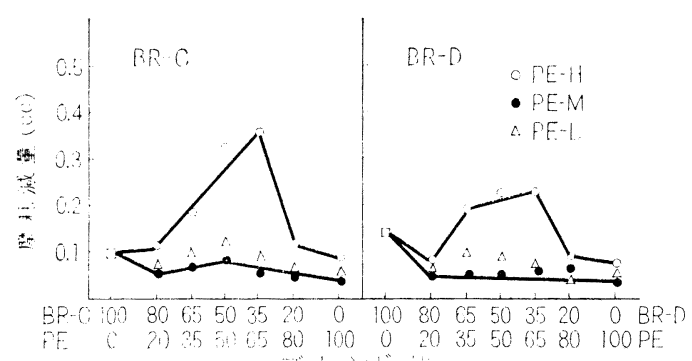

図16 BR/PE ブレンド物の摩耗性

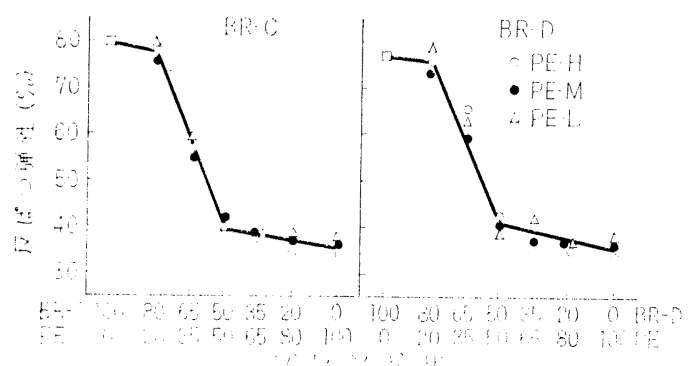

図17 BR/PE ブレンド物の反ぱつ弾性

2）ブレンド比による諸性質の変化は SBR ブレンド とほぼ同じ傾向を示し，BR，PE それぞれ単独の性 質とブレンド物の性質との間にはブレンド比 $50 / 50$ 近辺に変曲点を有する直線関係がみとめられる.

3） PE の種類による補強効果は, PE-H が最も小さ く, PE-M と L の差はほとんどみとめられない.

4） BR-G と BR-D の差はほとんどみとめられない.

5） $\mathrm{BR} / \mathrm{PE}$ 系は $\mathrm{SBR} / \mathrm{PE}$ 系より 加工性がやや良好で ネッキングの程度も小さい. また，データのバラッ キも SBR の場合より小さい.

以上のことから，PE は SBR に対するより，BR に対 してより効果的な低比重補強材といえる.

\section{4. ポリイソプレンゴムと ポリエチレンのブレンド}

IR と PE をロールブレンドし， IR/PE ブレンド比 $100 / 0 ， 75 / 25,50 / 50,25 / 75,0 / 100$ のブレンド物のイ オウ一促進剤系による加硫物の諸性質を調べた.

\section{1 実験方法}

4.1.1 試料および配合 IR にはカリフレックス 305 を用いた. PE および配合は前節と同じである（表 1 ， 2 抢よび 3 ).

4.1.2 混練および加硫 混練は $10^{\prime \prime} \times 20^{\prime \prime}$ 高圧蒸気加 熱式テストロール（前ロール回軽速度 $11 \mathrm{rpm}$, 回転比 1 ：1.27）を用いた. 混練手順，加硫は前節と同様におこ なった。

4.1.3 諸性質の試験法 加硫物の引張強さ, モジュ ラス, 伸び, かたさ, 摩耗抵抗, 引裂強さ, 耐油性を測 定した。試験法は JIS K 6301 に準じた。

引張試験：JIS 1 号ダンベル 型試験片, 引張速度 440 $\mathrm{mm} / \mathrm{min}$.

摩耗試験：アクロン式摩耗試験機, 取付角 $10^{\circ}$ 荷重 2.72 $\mathrm{kg}$

耐油試験：ASTM 3 号油 $70^{\circ} \mathrm{C}$ に浸漬，平衡膨潤後の体 積増加率を測定.

\section{2 実験結果および考察}

IR/PE ブレンド物は SBR, BR 系ブレンド物に比ベ著 しくロールに粘着し, 特に高温では混練操作が困難であ った. PE 量の多い試料では, やはりネッキングがみと められた.

加硫物の諸性質を図18〜24に示す，作業性の関係から PE-L のブレンド実験は不適当であるので中止した.

1）補強効果は PE 量にほぼ比例して增大し, PE-H はPE-M より效果がある.

2）概して $\mathrm{SBR} / \mathrm{PE}$ 系， BR/PE とほぼ同じことが、 える. ただし，引裂強さに対する効果が SBR の場 合に比べやや小さいこと，およびブレンド比 50/50 近辺での強度が低くなっていることなどが，前者と ことなっている.

以上のことから，IR は SBR や BR に比べ PE との 相容性が劣ってはいるが，同様化低比重補強材になりう ると思われる。

\section{5. ブチルゴムとポリエチレンのブレンド}

SBR,BR, IR についておこなったと同様に，ここでは IIR と PE のロールブレンド物の諸性質を調ベた.

\section{1 実験方法}

実験に用いた IIR はエンジエイブチル301である.

PE は前節と同じ PE-H および PE-M を用いた. 


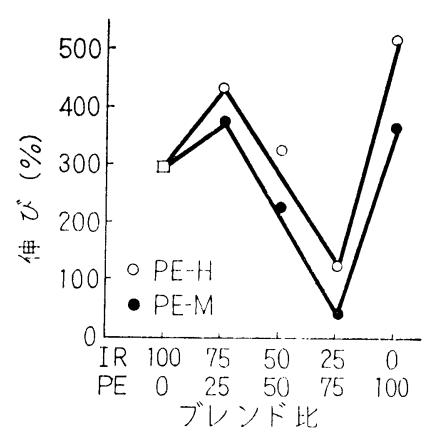

図18 IR/PEブレンド物の伸び

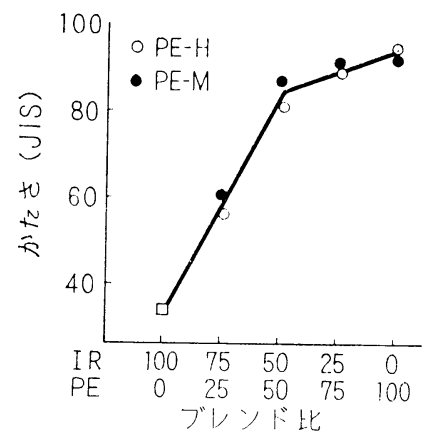

図21 IR/PEブレンド物のかたさ

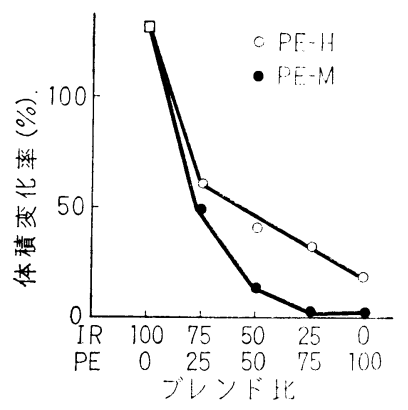

図24 IR/PEブレンド物の耐油性

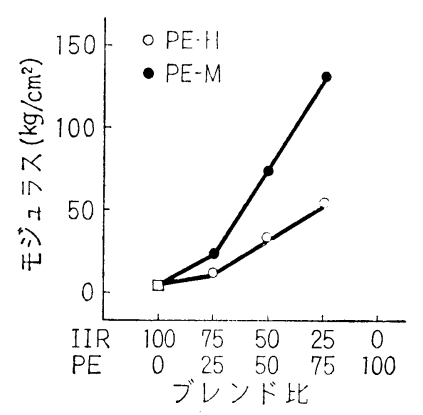

図27 IIR/PE ブレンド物のモジュ ラス $(100 \%)$

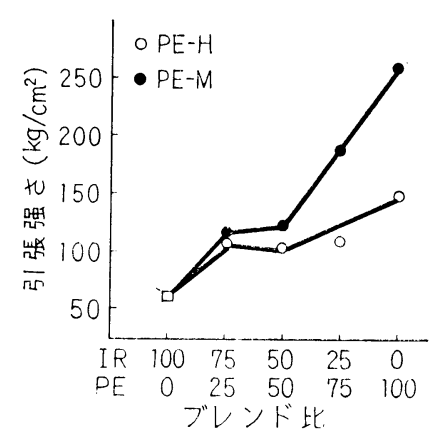

図19 IR/PEブレンド物の引張強さ

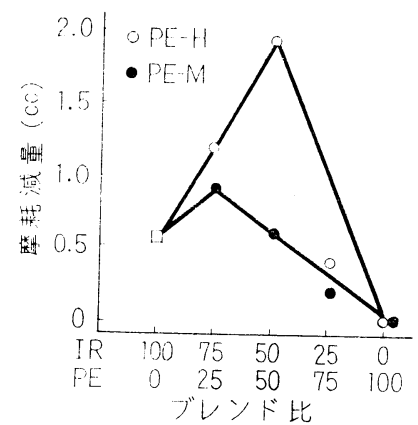

図22 IR/PEブレンド物の摩耗性

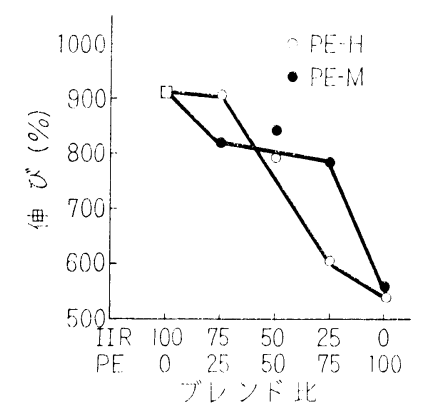

四25 IIR/PE ブレンド物の伸び

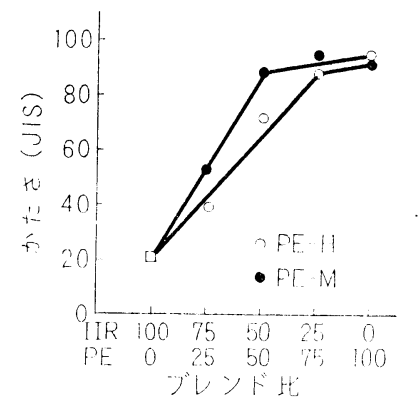

図28 IIR/PE ブレンド物のかたさ

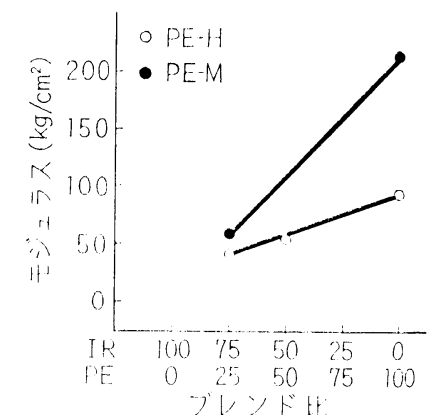

网20 IR/PEブレンド物のモジュラ ス $(300 \%)$

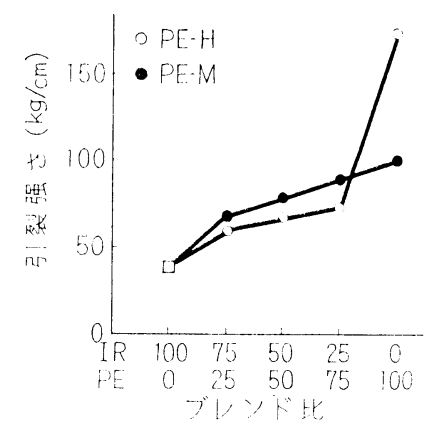

図23 IR/PEブレンド物の引裂強さ

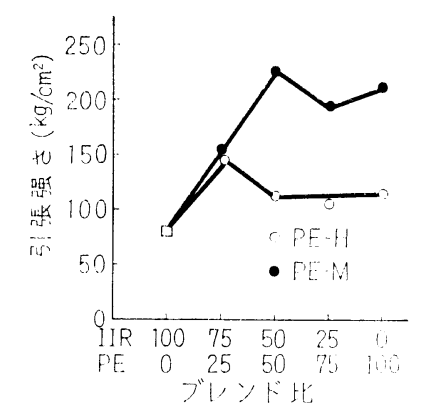

図26 IIR/PE ブレンド物の引張強 さ

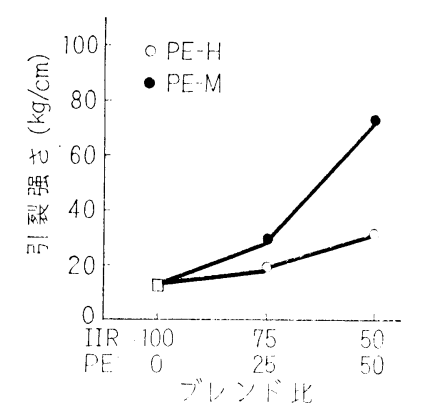

図29 IIR/PE ブレンド物の引裂強 さ 
表 $5 \quad 11 \mathrm{R} / \mathrm{PE}$ の配合

\begin{tabular}{|c|c|}
\hline 配 合 剤 & 重量部 \\
\hline ポリマー & 100 \\
\hline 要鉛華 ( 1 号) & 5. 0 \\
\hline 老化防止珮D & 1.0 \\
\hline ステアリン酸 & 1.0 \\
\hline イオウ & 1.75 \\
\hline 促進戍 CZ & 1.5 \\
\hline 促進剤 TT & 0.5 \\
\hline
\end{tabular}

配合を表 5 亿示寸，混練は前節（4.1）と同じロールで おこない, 混練手順, 加硫も同様におこなった.

加硫物の諸性質の試験も前節（4.1）に淮じた.

\section{2 実験結果および考察}

混練操作は SBR ブレンドと同程度に容易に扔こなう ことができ，加硫上りの状態はそれぞれ良好であった。

そして，PEの多、試料でもネッキングはほとんどみと

められなかった。

加硫物の諸性質を図25～29亿示す.

IIR/PE のブレンドもSBR，BR などの例と同様に，

補強效果壮 PE 量と直線関倸を示し, PE-H より PE-M の方が大きいが，つぎの点は IIR/PE ブレンドだけにみ とめられた特徵といえる.

1）伸びが PE 量が增すにしたがい，ほぼ直線的に低 下する.

2） IIR 量の多い部分での PE の補強効果が特に大き い.

IIR は純ゴム配合では加工性がよくないが $25 \%$ 程度 PE をブレンドすることによって作業性が大幅に改善さ れる.さらに，2）のように IIR 量の多い部分で大きな 補強効果がみとめられることなどから，すくなくとも機 械的強度を改善する目的に関するかぎり IIR/PE の組合 せは極めて効果的なものといえる。

\section{6. 総 括}

$\mathrm{SBR}, \mathrm{BR}, \mathrm{IR}$, およびIIR と重合法のことなる PE を ブレンドした結果 PE はこれらゴムに対しすぐれた低比 重補強材となりらることを知った。 そしてその補強效果 はPE が増加するにしたがい，直線的に增大する傾问が あることが認められた。

また補強効果は低圧>中圧>高压 PE の順に大であっ た、しかし，いずれの場合も PEがあまり多くなるとネ ッキングを起し，PE はイオウ加硫されていないものと 考えられた。

また BR/PE 系はSBR 系汇くらべ加工性がやや良好 であった. IIR は純ゴム配合では加工性が非常にわるい が，PE を25\%程度いれると作業性が非常に改善され たそそして，物理性質もよくなることより IIR/PEの組 合せは工業的にも意味があることをみとめた。

[付記〕この研究は昭和39年 3 月, 神戸で催され た坂井化学工業㹯主催「工場と研究室を結ぶ会（第 8 回)」で一部を発表した。

本研究のために試料ポリマーを提供頂いた旭化成工業

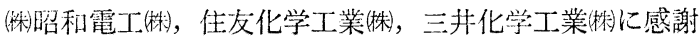
します.

また，本研究の発表を許可された上司の方々に感謝し ま子。

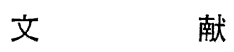

1）护本，筫浦ら，ゴム協 38，1007（1965）

2）井本，箕浦ら，ゴム協 38，481 (1965)； 38649 (1965); 38, 657 (1965)

\section{STUDIES ON THE BLEND OF RUBBER LIKE MATERIALS AND THERMOPLASTIG RESINS.}

\section{BLENDING OF VARIOUS RUBBER AND POLYETHYLENE.}

M. Imoto, Y. Minoura (Osaka City University, the faculty of Engineering)

K. Goto (Osaka Institute of Technology, Department of Applied Chemistry)

A. Yabe (Fukusuke Corporation)

M. Takimiya (Hiroshima Kasei Ltd.)

I. Ando (Mitsuboshi Belting Ltd.)

Y. Imakuma (Mitsuuma Rubber Co.)

H. Kenbishi (Naigai Rubber Industry Co. Ltd.)

S. Yabuta (Japan Synthetic Rubber Co. Ltd. Kansai Processing Research Inst.)

T. Hidaka (Japan Synthetic Rubber Co. Ltd. Yokkaichi Plant)

K. Komuro ('The Japanese Geon Co. Ltd.)

H. Tahara (Nippon Valqua Ind, Co.)

M. Shundo (Sakai Chemical Industrial Co. L.td.)

K. Mega (Taiyo Rubber Factory, Ltd.)

The properties of the blends which consist of various rubber (SBR, BR, IR, IIR) and polyethylene (which are classed by the pressure of polymerization reaction such as High-pressure, Medium-pressure and Lowpressure) were studied. It was found that (1) polyethylenes are usefull as low-density reinforcing agent for rubbers, and the classification of reinforcing effect is as follows, Low-pressure $>$ Medium-pressure $>$ Highpressure, (2) the combination of IIR and polyethylene of all blends is of the most value to industrial use. 